\title{
Using Technology to Enhance Learning: Computer Science Lecturers' Perceptions towards Mobile Technology and Serious Games in Class
}

\author{
DB Jordaan \\ J Surujlal \\ North-West University, Faculty of Economic Sciences and Information Technology \\ PO Box 1174, Vanderbijpark, 1900, Republic of South Africa \\ E-mail: Dawid.Jordaan@nwu.ac.za
}

\author{
Doi:10.5901/mjss.2014.v5n13p487
}

\begin{abstract}
The use of mobile technology determines the way of live of students as they are using the latest technologies to create new things in new ways, learn new things in new ways, and communicate in new ways with people. They read less because they are more comfortable in image-rich environments than with text and prefer active, first-person, and experiential learning vibrantly present in new media technology but lacking in traditional lectures. Introducing serious games into classroom and the potential value thereof has received wide attention recently. Many studies report that serious games can motivate and encourage students to be problem solvers because of built-in motivation and familiarity features. Integrating technology and serious games into the teaching-learning process depends mainly on the lecturer. Lecturers' perceptions of the role of technology and serious games in class may hinder their readiness and confidence in using it in class. The purpose of this research is therefore to determine the perceptions of Computer Science lecturers towards mobile technology and serious games in class. A quantitative research approach involving the administration of a structured questionnaire to Computer Science lecturers was used to collect data for the study. Data was collected at two different university campuses. The questionnaire included questions on demographics and two areas, namely attitudes towards mobile technology in class and attitudes about serious games in class. Within these two areas perceptions regarding the following factors were measured: a) attitude towards the use of mobile technology and serious games in class; b) potential benefits of integrating mobile technology and serious games in lessons and c) intention to use mobile technology and serious games in class. The study revealed that Computer Science lecturers have a positive attitude towards the use of technology and serious games in class and realise the potential benefits of using technology and serious games in class. It is clear from the results that laptops and tablets are preferred in class as there is a huge negative response with regard to the use of cell phones in class.
\end{abstract}

Keywords: Mobile technology, serious games, Computer Science lecturers' perceptions

\section{Introduction}

Now, more than ever before, technology is becoming increasingly integrated into our lives and society. The emergence of social networking technologies are shaping the way in which people communicate, collaborate, think, work, live and form social constructs (Klopfer, Osterweil, Groff \& Haas, 2009).

It is difficult to imagine the current modern university student living a life without spending a substantial amount of time on their smartphones chatting, browsing the web, texting, blogging, playing games or visiting online communities such as Facebook, Twitter, and WhatsApp (Kron, Gjerde, Sen \& Fetters, 2010; Kurkovsky, 2009). Students nowadays are almost fully integrated into technology, using the latest technologies to create new things in new ways, learn new things in new ways, and communicate in new ways with new people - behaviours that have become a way of life for them. It is therefore not surprising that they are more comfortable in image-rich environments than with text because they read less (Sweeny, 2007) and have a preference for active, first-person, experiential learning that is lacking in traditional lectures, but vibrantly present in new media technology (Lenhart, Madden \& Hitlin, 2005).

The integration of technology in education is no longer a novel idea. Given the fact that technology has become an integral part of society - academic institutions, business, medicine, science and government are using it - it has now become necessary to integrate its use in education (Rodgers, 2014).

Numerous advantages have been found regarding the use of technology in the classroom. Given the fact that technology has the potential to add variety in the classroom, it can assist in keeping students more focused, more motivated and engaged for longer periods of time. Unlike traditional teaching aids, technology can instil in students excitement about learning. Another advantage is that technology allows students to work at their own pace, set goals, 
learn in different environments, monitor and assess their progress, think critically and work without the teacher/lecturer being present. From an educator viewpoint, technology can aid in teaching more in a shorter time and reduce the number of times the educator needs to repeat information. The diversity of the types of technology available for teaching (e.g. digital games, laptops, tablets, smart phones, i-pads) provide a richer experience in terms of sound and graphics as well as choice to the students. Students are also able to access information at a faster pace and on demand. It also provides for the storage as well as retrieval of information. Rodgers (2014) opines that technology is especially appropriate for the enhancement of global studies as it can bring experiences of other cultures vividly into the classroom. It also provides multiple communication channels for students to communicate locally as well as across the globe. Not only does telecommunications allow for interaction between students, it also encourages creative opportunities to be formed by showing the interrelationships among the social studies, literature, art and music. Contrary to the belief that technology can lead to ill-discipline, the embedded rules, goals and objectives in digital games and computer programmes provide for purposeful, rule-based activities which can be both educational as well as fun (Klopfer, 2008).

Rodgers (2014) opines that technology can improve students' problem-solving and critical thinking skills, their writing and math skills, and their computer skills. This is especially critical given the fact that technology is used in almost every sphere of life.

\section{The Use of Mobile Technology and Serious Games in Teaching Computer Science Modules}

Klopfer et al. (2009) suggest that the emergence of new technologies encourage educators to understand, lever and implement them in the classroom. The authors argue that while there is no doubt effective classroom lessons and objectives can be achieved without the latest technologies, there will be a sharp disconnect between the way students are taught and the way they interact and socialise with the outside world if the current available technologies are not used in the classroom. Many technologies exist which can be used to enhance the learning experience of students. The current article focuses on mobile technology and serious games.

While desktop computers are mainly used to teach the vast majority of Computer Science (CS) modules, Kurkovsky (2009b) suggests that students increasingly relate computing technology with mobile devices rather than with desktop computers. Mahmoud (2008) introduced mobile devices into programming courses and achieved excellent results in terms of student enthusiasm and satisfaction. Students could learn with mobile devices when they learn concepts and content related to the curriculum as this will not only expand and enhance the learning objectives but also fit well with modern students' learning styles (Kron et al., 2010). The challenge, however, according to Reardon \& Tangney (2011), is to apply a teaching approach which exploits the capabilities of mobile devices and increases students' interest in mobile devices. Such an approach is a good opportunity to encourage and stimulate student interest in Computer Science (Kurkovsky, 2009a).

The number of undergraduate students enrolled in computer science-related programs has declined considerably (Computer Society Connection, 2008; Schroeder, 2011). Kurkovsky (2009b:44) attributes this, "...among other factors, to the decreased appeal of computer science as an academic discipline or career choice". In many cases Computer Science students end up changing majors after the first or second year of study because they find the course material irrelevant to practical applications (Beaubouef \& Mason, 2005). Kurkovsky (2009b) argues that if this situation is to be reversed it is very important for the Computer Science curriculum to stay applicable and relevant to today's reality and engage students by making a strong connection between computing and students' everyday lives. Students need a conducive, creative and challenging classroom environment to which they can relate and make a difference in preparing for their careers (Kurkovsky, 2009b). In this way "we nurture a new generation of creative, systematic thinkers who are comfortable in using programming to express their ideas" (Resnick, Maloney, Hernández, Rusk, Eastmond, Brennan et al., 2009:60).

Serious games are games with an educational intent and need to be engaging while the learning can be implicit or explicit (Ulicsak \& Wright, 2010). From the many definitions of serious games (Garris, Ahlers \& Driskell, 2002; Micheal \& Chen, 2006; Vogel, Vogel, Cannon-Bowers, Bowers, Muse \& Wright, 2006; Wouters, van der Spek \& van Oostendorp, 2009) one can conclude that a serious game is goal-directed, has a competitive activity and is conducted within a framework of agreed rules (Lindley, 2004) and enable players to monitor their progress towards the goal, while providing constant feedback (Prensky, 2001). The value of introducing serious games in the classroom has also received wide attention recently (Kurkovsky, 2009b). Many studies (e.g. Moses, Khambari \& Wong, 2008; Barnes, Richter, Chaffin, Godwin, Powell, Ralph et al., 2007; Becker, 2001; Prenski, 2001; Gumhold \& Weber, 2004) report that serious games have a built-in motivation and familiarity which can motivate and encourage students to be problem solvers. Furthermore, learning is improved when teaching is grounded in familiar, concrete and relevant examples (Hennessy, Harrison \& 
Wamakote, 2010; Bransford, Brown \& Cocking, 1999).

The integration of technology and serious games into the teaching-learning process depends mainly on the lecturer (Cui \& Wang, 2008; Moses et al., 2008). Prominent factors like attitudes, expertise, lack of autonomy and lack of knowledge to evaluate the use and role of technology and serious games in class may hinder a lecturer's readiness and confidence in using technology support in class (Hennessy et al., 2010). It is often considered that lecturers' instructional beliefs play a fundamental role in their classroom practice (Liu, 2007).

Educational technologies should be embraced as another tool to change our teaching, our learning, and our classrooms. However, it should not be "seen just as a new tool for an old task, rather as a new tool that can help us think differently about teaching and help our students think differently about learning" (Wehrli, 2009:4).

\section{Rationale for the Study}

The rapid growth of mobile technologies and educational games that have 'invaded' the lives of educators and students globally provides an interesting avenue for the introduction of different teaching and learning methods. The measurement of lecturers' perceptions towards the use of them may be critical in establishing appropriate interventions to help lecturers integrate these resources into teaching and learning (Chao, 2005:3). The results may be useful in determining whether their experiences and perceptions warrant the development of teaching methods that make use of mobile devices and serious games. It may also help better understand how those applications should be designed so as to resonate strongly with students.

\section{Purpose of this Study}

The purpose of this study was to examine Computer Science lecturers' experience with, and attitudes towards mobile technology and serious games in class

\section{Research Methodology}

A quantitative research approach was adopted for the study. This approach was chosen because it provides a quick, inexpensive, efficient and accurate means of accessing the desired information (Zikmund, Babin, Carr \& Griffin, 2010). In addition, an appropriate literature review on serious games and mobile technology as educational aids was conducted. Arising from the literature review a questionnaire was developed to investigate lecturers' perceptions towards mobile technology and serious games in class.

\section{Sample}

The sample for the study comprised thirty two Computer Science lecturers from two university campuses in the Gauteng province of South Africa.

\section{Research Instrument and Procedure}

The questionnaire used to collect data comprised thirty eight items which included questions on demographics and two areas, namely attitudes towards mobile technology in class and attitudes about serious games in class. Within these two areas perceptions regarding the following factors were measured: a) attitude towards the use of mobile technology and serious games in class; b) potential benefits of integrating mobile technology and serious games in lessons and c) intention to use mobile technology and serious games in class. The perception items were scored on a 5-point Likert-type scale anchored at 1 (strongly disagree) and 5 (strongly agree).

The questionnaire was administered personally to the participants by the principal researcher. At the outset the purpose of the study was explained to the participants. They were informed that their participation was voluntary and the data collected from the study would be reported in an aggregate format. Anonymity and confidentiality were also assured to all participants.

\section{Data Analysis}

The Statistical Package for the Social Sciences (SPSS - version 21) was used to analyse the data. The reliability of the 
questionnaire was ascertained using Cronbach alpha. Frequencies are used to report on the results. Reliability of the questionnaire was found to be 0.771 .

\section{Results and Discussion}

Of a total of 32 questionnaires which were administered, 22 completed questionnaires (response rate $=69 \%$ ) were returned.

Table 1 provides the demographic information of the respondents. According to Table 1 the majority of respondents were female $(n=13)$ and were 30 years and older $(n=16)$. Regarding their experience the majority $(n=14)$ had six years and more teaching experience. Besides two responses which reflected 'other' as a main interest all respondents' main interest was in the mathematics $(n=5)$, statistics $(n=3)$ and technology/Computer Science $(n=28)$ field.

Table 1 Demographics

\begin{tabular}{|l|c|}
\hline \multicolumn{2}{|l|}{ Total } \\
\hline Age group & 6 \\
\hline $20-29$ & 8 \\
\hline $30-39$ & 4 \\
\hline $40-49$ & 4 \\
\hline $50-59$ & 8 \\
\hline Tertiary teaching experience (years) & 3 \\
\hline $0-5$ & 8 \\
\hline $6-10$ & 3 \\
\hline $11-20$ & \\
\hline $21-30$ & 13 \\
\hline Gender & 9 \\
\hline Female & \\
\hline Male & 5 \\
\hline Main Academic interest (participants could choose one or two options) & 3 \\
\hline Mathematics & 6 \\
\hline Statistics & 2 \\
\hline Data bases Data warehouses & 3 \\
\hline Operating systems & 6 \\
\hline Computer networks & 7 \\
\hline Programming & 1 \\
\hline System analysis \& design & 3 \\
\hline Decision support systems & 2 \\
\hline Human-computer interaction & \\
\hline Other &
\end{tabular}

Table 2 illustrates the participants' attitudes towards the use of technology in class. For the purpose of discussion of Table 2, Table 3 and Table 4 the scores "strongly agree" and "agree" are combined and "agree" and "strongly agree" are combined.

From Table 2 it is clear that all lecturers are confident with cell phones (100\%) and laptops (100\%) while only $45 \%$ are comfortable with tablets. The majority $(73 \%)$ are not in favour that students should be issued with cell phones, while with laptops they are fairly neutral. A small majority (55\%) are in favour that students should be issued with tablets. In response to use of technology during theoretical tests and examinations, the majority (73\%) are against the use of cell phones, while with laptops and tablets they are neutral (50\% for and $50 \%$ against the use of laptops and $45 \%$ for, $45 \%$ against; and the rest is undecided regarding the use of tablets). Lecturers' views change dramatically when asked whether technology can be used during practical tests and examinations. In this case they are neutral (45\% for, 36\% against; and the rest are undecided) with regard to the use of cell phones, but strongly in favour of the use of laptops $(82 \%)$ and tablets $(64 \%)$. Half of the respondents do not mind if a student uses his/her own device (cell phone, laptop or tablet) during practical sessions. Lecturers' responses are neutral when asked whether it is difficult to control the use of technology in class. The majority $(68 \%)$ do not think that "serious games" is just a buzz word while $5 \%$ think that it is a buzz word (the rest is unsure). 
Table 2 Attitudes towards the use of technology in class

\begin{tabular}{|c|c|c|c|c|c|}
\hline 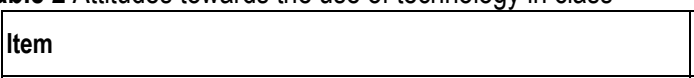 & $\begin{array}{l}\text { Strongly } \\
\text { disagree }\end{array}$ & Disagree & $\begin{array}{l}\text { Neither agree } \\
\text { nor disagree }\end{array}$ & Agree & $\begin{array}{c}\text { Strongly } \\
\text { agree }\end{array}$ \\
\hline I am familiar with cell phones & 0 & 0 & 0 & 7 & 15 \\
\hline I am familiar with laptop computers & 0 & 0 & 0 & 7 & 15 \\
\hline I am familiar with tablets & 3 & 4 & 5 & 4 & 6 \\
\hline I think students should be issued with cell phones & 12 & 4 & 3 & 3 & 0 \\
\hline I think students should be issued with laptops & 5 & 2 & 6 & 5 & 4 \\
\hline I think students should be issued with tablets & 4 & 0 & 6 & 6 & 6 \\
\hline $\begin{array}{l}\text { I think students should be allowed to use cell phones during } \\
\text { theoretical tests/theoretical exams }\end{array}$ & 15 & 1 & 2 & 2 & 2 \\
\hline $\begin{array}{l}\text { I think students should be allowed to use laptops during theoretical } \\
\text { tests/theoretical exams }\end{array}$ & 11 & 0 & 0 & 6 & 5 \\
\hline $\begin{array}{l}\text { I think students should be allowed to use tablets during theoretical } \\
\text { tests/theoretical exams }\end{array}$ & 10 & 0 & 2 & 4 & 6 \\
\hline $\begin{array}{l}\text { I think students should be allowed to use cell phones during } \\
\text { practical tests/ practical exams }\end{array}$ & 9 & 1 & 4 & 4 & 4 \\
\hline $\begin{array}{l}\text { I think students should be allowed to use laptops during practical } \\
\text { tests/ practical exams }\end{array}$ & 2 & 0 & 2 & 6 & 12 \\
\hline $\begin{array}{l}\text { I think students should be allowed to use tablets during practical } \\
\text { tests/ practical exams }\end{array}$ & 2 & 0 & 6 & 3 & 11 \\
\hline $\begin{array}{l}\text { I think students should be allowed to use a device of their own } \\
\text { choice during practical sessions }\end{array}$ & 6 & 3 & 2 & 6 & 5 \\
\hline It is difficult to control the use of cell phones/laptops/tablets in class & 3 & 5 & 5 & 5 & 4 \\
\hline "Serious games" is just a buzz word. & 9 & 6 & 6 & 0 & 1 \\
\hline I play serious games. & 5 & 4 & 5 & 4 & 4 \\
\hline
\end{tabular}

Table 3 illustrates how participants' see the potential benefits of using technology in class. From Table 3 it is evident that lecturers are aware of serious games and are overwhelming positive about the potential benefits of using it in class. $86 \%$ indicated that serious games are goal-directed; $86 \%$ agree that serious games provide feedback to the player; $77 \%$ believe that serious games are conducted within a framework of agreed rules; and $86 \%$ agree with the broad definition that a serious game is a game with educational value. A small majority (55\%) disagrees that it will be difficult to assess the contribution that serious games make to the learning process but the majority $(82 \%)$ feels that serious games can enhance learning.

Table 3 Potential benefits of using of technology in class

\begin{tabular}{|l|c|c|c|c|c|}
\hline Item & $\begin{array}{c}\text { Strongly } \\
\text { disagree }\end{array}$ & Disagree & $\begin{array}{c}\text { Neither agree } \\
\text { nor disagree }\end{array}$ & $\begin{array}{c}\text { Agree } \\
\text { Strongly } \\
\text { agree }\end{array}$ \\
\hline Serious games are goal-directed & 0 & 0 & 3 & 9 & 10 \\
\hline Serious games provide feedback to the player & 0 & 0 & 3 & 10 & 9 \\
\hline Serious games are conducted within a framework of agreed rules & 0 & 0 & 5 & 8 & 9 \\
\hline $\begin{array}{l}\text { It will be difficult to assess the contribution that serious games make to } \\
\text { the learning process }\end{array}$ & 4 & 8 & 6 & 3 & 1 \\
\hline A serious game is a game with educational value & 0 & 0 & 3 & 8 & 11 \\
\hline Ithink serious games can enhance learning & 0 & 2 & 1 & 7 & 12 \\
\hline I have used serious games in class & 12 & 6 & 2 & 1 & 1 \\
\hline I plan to use serious games in class in future & 3 & 3 & 4 & 7 & 5 \\
\hline A good serious game masters the art of creating motivation & 1 & 1 & 4 & 11 & 5 \\
\hline $\begin{array}{l}\text { A good serious game balance game and learning goals with a tight focus } \\
\text { on relevant educational content. }\end{array}$ & 1 & 1 & 2 & 14 & 4 \\
\hline Students need a classroom experience which is creative and challenging & 0 & 0 & 4 & 5 & 13 \\
\hline $\begin{array}{l}\text { Students are taught in a context that does not match their interest and } \\
\text { experience }\end{array}$ & 2 & 3 & 4 & 7 & 6 \\
\hline $\begin{array}{l}\text { Experience in mobile applications and game development is a skill in high } \\
\text { demand by industry }\end{array}$ & 0 & 2 & 5 & 10 & 5 \\
\hline Serious games will attract students to the school & 0 & 3 & 2 & 10 & 7 \\
\hline Serious games have the ability to transform education & 0 & 1 & 4 & 9 & 8 \\
\hline
\end{tabular}


Despite the potential benefits of serious games in class $82 \%$ of the participants indicated that they have not used serious games in class and only a small majority (55\%) plan to use it in class in future. Reasons for this might become clear in the discussion of the participants' intention to use technology in class in the next section. $73 \%$ participants are in agreement that a good serious game is motivational and $82 \%$ are of the opinion that a good serious game balances game and learning goals with a tight focus on relevant educational content. While $82 \%$ of the participants felt that a creative and challenging classroom experience is needed for the students, $59 \%$ agree that students are not taught in a context where their interest and experience are taken in account.

The need for mobile application and game development skills by industry is recognised by $68 \%$ of the respondents, $77 \%$ believe that the use of serious games in class will attract students to school and the majority $(77 \%)$ indicated that the use of serious games in class have the ability to transform education.

Table 4 illustrates participants' intention to use technology in class.

Table 4 Participants' intention to use technology in class

\begin{tabular}{|l|c|c|c|c|c|}
\hline Item & $\begin{array}{c}\text { Strongly } \\
\text { disagree }\end{array}$ & Disagree & $\begin{array}{c}\text { Neither agree } \\
\text { nor disagree }\end{array}$ & $\begin{array}{c}\text { Agree } \\
\begin{array}{l}\text { Strongly } \\
\text { agree }\end{array}\end{array}$ \\
\hline $\begin{array}{l}\text { I will welcome serious games in my class if someone else provides } \\
\text { them to me }\end{array}$ & 2 & 1 & 2 & 8 & 9 \\
\hline I would like to be part of a design team that creates serious games & 3 & 1 & 3 & 8 & 7 \\
\hline I don't have time to search for serious games in my field of interest & 1 & 7 & 7 & 5 & 2 \\
\hline I don't have time to write games & 2 & 8 & 3 & 3 & 6 \\
\hline Serious games will only waste class time & 8 & 8 & 3 & 2 & 1 \\
\hline I don't have time to integrate serious games in my lecture & 6 & 7 & 4 & 3 & 2 \\
\hline Students can play serious games at home & 2 & 0 & 4 & 8 & 8 \\
\hline
\end{tabular}

When analyzing participants' intention to use technology it is evident that there are positive intentions to use serious games in class but it seems that there is uncertainty about the choice of serious games (or a lack of a model or framework to integrate serious games into class) as $77 \%$ of the participants indicated that they will use serious games in class if serious games are provided to them. There is a willingness $(68 \%)$ to be part of a design team that creates serious games but respondents seem undecided about the time needed to search or write serious games. The majority $(73 \%)$ indicated that using serious games in class will not be a waste of class time and $59 \%$ indicated that they will have time to integrate serious games into the class.

Gaming and mobile technology are fast becoming a widespread culture in many learning programmes in higher education institutions (Feller, 2006). The use of mobile technology and serious games, both inside and outside the classroom, provides swift access, processing and understanding of information. Given the positive perceptions of the participants of this study, it is highly likely that technology will be embedded in the most curricula in the near future.

\section{Limitation and Implications for Further Research}

A limitation of the study is the nature of the sampling method. A non-probability convenience sampling method in a single province in South Africa was used. Therefore caution should be exercised when generalizing the perceptions of Computer Science lecturers towards mobile technology and serious games in class to other provinces. Notwithstanding this limitation, this study makes a significant contribution to the knowledge base of the perceptions of Computer Science lecturers towards mobile technology and serious games.

Arising from the results of the study are implications for further research. Extending the study to other universities in other provinces in South Africa and comparing the results may provide a more comprehensive illustration of the perceptions of Computer Science lecturers towards mobile technology and serious games.

\section{Conclusion}

The purpose of this study was to investigate the Computer Science lecturers' perceptions towards mobile technology and serious games in class. The study revealed that Computer Science lecturers have a positive attitude towards the use of technology and serious games in class. The majority indicated that there are potential benefits in using technology in class and participants' intention to use technology in class is commendable. The results indicate that laptops and tablets are preferred in class as there is a huge negative response with regard to the use of cell phones in class.

$$
\sim 492 \sim
$$




\section{References}

Barnes, T., Richter, H., Chaffin, A., Godwin, A., Powell, E., Ralph, T., Matthews, P. \& Jordan, H. (2007). Game2Learn: A study of games as tools for learning introductory programming concepts. SIGCSE, USA.

Beaubouef, T. \& Mason, J. (2005). Why the high attrition rate for computer science students: some thoughts and observations, SIGCSE Bulletin, 37, 2, June, pp. 103-106.

Becker, K. (2001). Teaching with games: The Minesweeper and Astrids experience. The Journal of Computing in Small Colleges, 17, (2), 22-32.

Bransford, J., Brown, A., \& Cocking, R. (1999). How People Learn: Brain, Mind, Experience and School. National Academy Press, Washington, DC.

Chao, C.C. (2005). Evaluating teachers' attitudes towards the use of wireless-mobile technologies in supporting learning: an instrument development study. Proceedings of the IEEE International Workshop on Wireless and Mobile Technologies in Education (WMTE'2005).

Computer Society Connection. (2008). Computer Science enrolments drop. Computer, 41, (4), 87-89.

Cui, G. \& Wang, S. (2008). Adopting cell phones in EFL teaching and learning, Journal of Educational Technology Development and Exchange, 1, (1), 68-80.

Feller, B. (2006). Scientists say video games can reshape education. The Seattle Times, October 18.

Garris, R., Ahlers, R. \& Driskell, J.E. (2002). Games, motivation, and learning: A research and practice model. Simulation \& Gaming, 33, $441-467$.

Gumhold, M. \& Weber, M. (2004). Motivating CS students with game programming. Proceedings of the 6th International Conference on New Education Environments (ICNEE), Neuchatel, Switzerland, Sep. 27-30.

Hennessy, S., Harrison, D. \& Wamakote, L. (2010). Teaching factors influencing classroom use of ICT in Sub-Saharan Africa. Itupale Online Journal of Africa Studies, 2, 39-54.

Klopfer, E. (2008). Augmented Learning: Research and Design of Mobile Educational Games. Cambridge, MA: MIT Press.

Klopfer, E., Osterweil, S., Groff, J. \& Haas, J. (2009). The instructional power of digital games, social networking simulations and how teachers can leverage them. Available at http://creativecommons.org/licenses/by/3.0. Accessed on 2014/01/17.

Kron, F.W., Gjerde, C.L., Sen, A. \& Fetters, M.D. (2010). Medical student attitudes toward video games and related new media technologies in medical education. BMC Medical Education, 10:50. Available at: http://www.biomedcentral.com/1472-6920/10/50. Accessed on: 20 March 2012.

Kurkovsky, S. (2009). Can mobile game development foster student interest in computer science? Paper presented at the Games Innovations Conference, 2009. ICE-GIC 2009. International IEEE Consumer Electronics Society's.

Kurkovsky, S. (2009b). Engaging students through mobile game development. ACM SIGCSE Bulletin, 41(1), 44-48.

Lenhart, A., Madden, M. \& Hitlin, P. (2005). Teens and Technology: Youth are leading the transition to a fully wired and mobile nation. Pew Internet \& American Life Project. 1615 L ST., NW - Suite 700, Washington, D.C. 20036. Available at: http://www.pewinternet.org/ /media/Files/Reports/2005/PIP_Teens_Tech_July2005web.pdf.pdf. Accessed on: 20 March 2012.

Lindley, C.A. (2004). Narrative, game play, and alternative time structures for virtual environments. In S. Gobel, U. Spierling, A. Hoffman, I. lurgel, O. Schneider, J. Dechau \& A. Feix (Eds.), Lecture Notes in Computer Science: Vol. 3105. Technologies for Interactive Digital Storytelling and Entertainment (pp. 183-194). Heidelberg: Springer Berlin.

Liu, T.C. (2007).Teaching in a wireless learning environment: A case study. Educational Technology \& Society, 10(1), 107-123.

Mahmoud, Q.H. (2008). Integrating mobile devices into the computer science curriculum. Paper presented at the $38^{\text {th }}$ ASEE/IEEE Frontiers in Education Conference, Saratoga Springs, NY. October 22-25.

Michael, D. \& Chen, S. (2006). Serious Games: Games that Educate, Train, and Transform. Boston, MA. Thomson Course Technology.

Moses, P., Khambari, M.N. \& Luan, W. S.. (2008). Laptop use and its antecedents among educators: A review of the literature. European Journal of Social Sciences, 7(1), 104-114.

Prensky, M. (2001). Digital Game-Based Learning, New York, McGraw-Hill.

Reardon, S., \& Tangney, B. (2011). Studio-Based Learning with Smartphones for Novice Programmers. Paper presented at the $10^{\text {th }}$ World Conference on Mobile and Contextual Learning, Beijing, China, October 18-21.

Resnick, M., Maloney, J., Hernández, A.M., Rusk, N., Eastmond, E., Brennan, K., Millner, A., Rosenbaum, E., Silver, J., Silverman, B. \& Kafai, Y. (2009). Scratch: Programming for All, Communications of the ACM, 52(11), 60-67.

Rodgers, W. (2014). Technology in the classroom. Available at http://www.shelbyed.k12.al.us/schools/rms/faculty /wrodgers/technology\%20int/students.html. Accessed on 2014/01/15

Schroeder, U. (2011). A bouquet of measures to promote computer science in middle \& high schools. Keynote talk, ITiSCE'11, Darmstadt, Germany, June 27-29.

Sweeny, R.T. (2007). How the new generation of well-wired multitaskers is changing campus culture. Chronical of Higher Education, 53(13). Available at: http://chronicle.com/article/How-the-New-Generation-of/10203. Accessed on: 18 March 2012.

Ulicsak, M. \& Wright, M. (2010). Games in education: serious games. A Futurelab literature review. Futurelab, 1 Canons Road, Harbourside, Bristol BS1 5UH, United Kingdom, June. Available at: www.futurelab.org.uk. Accessed on: 18 March 2012.

Vogel, J.J., Vogel, D.S., Cannon-Bowers, J., Bowers, C.A., Muse, K. \& Wright, M. (2006). Computer gaming and interactive simulations for learning: A meta-analysis. Journal of Education Computing Research, 34, 229-243.

Wehrli, B. (2009). Technology as a fence and a bridge, Coalition of Essential Schools. Available at: 
http://www.essentialschools.org/resources/431. Accessed on 22 March 2012.

Wouters, P., Van Der Spek, E. \& Van Oostendorp, H. (2009). Current practices in serious game research: A review from a learning outcomes perspective. In T. Connolly, M. Stansfield \& L. Boyle (Eds.), GamesBased Learning Advancements for MultiSensory Human Computer Interfaces: Techniques and Effective Practices (pp. 232-250). Hershey, PA: IGI Global.

Zikmund, W.G., Babin, B.J., Carr, J.C. \& Griffin, M. (2010). Business Research Methods, $8^{\text {th }}$ ed. Southern-Western: Centage Learning. 